\title{
Preferences-Based Approach for TRIZ Contradiction Matrix Exploitation in Preliminary Design \\ Doctor in
} ENSAM-Meknès Moulay Ismail University Morocco

Mehdi EL Amine

Assistant Professo ENSAM-Meknès Moulay Ismail University Morocco

Larbi Lasri

Hability Professor ENSAM-Meknès Moulay Ismail University Moroccco

Mohammed Sallaou

University Professor ENSAM-Meknès Moulay Ismail University Morocco
The TRIZ theory has demonstrated its effectiveness in solving creative problems in the product design field. However, its exploitation and the application of its various tools and techniques remain difficult for the nonexperts. Generally, the theory does not offer the necessary tools in the preprocessing phases, to support problem modeling. In this context the aim of many research studies is to make easier the TRIZ tools exploitation. The work developed in this paper deals with the TRIZ contradiction matrix exploitation difficulty, and focuses on technical contradictions established for a complex system prioritizing. The technical contradictions prioritizing will be achieved through induced effects impact evaluation on the different specified design objectives. The proposed approach allows analyzing and structuring the design problem in order to exploit the TRIZ contradiction matrix for the design problem resolving. The proposed approach responds to the main problems raised during TRIZ matrix exploitation, especially problems related to the abstraction process ie the standard contradiction formulation and their hierarchy. This aim is achieved through the decision-maker preferences (DMP) integration. An illustration of the proposed approach is carried out with a case study on the wind system.

Keywords: TRIZ, contradiction matrix, induced effects, decision-maker preferences (DMP), preliminary design, wind system.

\section{INTRODUCTION AND CONTEXT}

Today innovation has become a crucial need for companies to evolve, thus the adoption of innovation support processes by industries has become fundamental. The innovation aspect integration first requires a specific choice of tools to promote the designer's ideation spirit, and Second the tools implementation in appropriate phases of the design process. Thus the presence of the innovation aspect in the product design process is currently needed. The integration of this aspect must be realized through specific methods and powerful tools, appropriate for different phases of the design process. The study conducted in this work is based on the Russian TRIZ (Theory of Inventive Problem Solving) developed by Genrich Altshuller in 1960 [1]. Given its efficiency and performance in solving innovative problems, the theory has since its inception a very wide exploitation in different areas [2]. Yet the TRIZ tools implementation difficulty limit its exploitation, especially with the beginners. In this context, many research studies have been developed to simplify, formalize and assist its implementation [3]. Research studies in this context often focus on combining TRIZ with other analysis and formulation tools [4-9]. In the present work, we are particularly interested to the TRIZ contradiction matrix tool forma-

Received: February 2020, Accepted: April 2020

Correspondence to: Dr Khadija Hmina, d'Etat Arts \&

Métiers, Génie Mécanique, Equipe Mécanique et Ingénierie Intégrée (M2I) ENSAM-Meknès, Maroc

E-mail: hminakhadija@gmail.com

Doi: $10.5937 / \mathbf{f m e 2 0 0 3 5 8 8 H}$

(C) Faculty of Mechanical Engineering, Belgrade. All rights reserved lization frequently used in the technical field to solve creativity problems [2], but also presenting several difficulties during its exploitation. In this subject, the literature has presented various works that tried to formalize the matrix exploitation responding to a specific limit. As an algorithm for design concept generation using TRIZ inventive principles was developped to resolve multi-parameter contradiction [10], another work proposes a semistructured contradiction matrix that uses physical quantities in SI unit instead of the TRIZ engineering parameters to enable exact and partial match in searching for relevant contradictions [11], A study was carried out proposing new characteristics and inventive principles for TRIZ contradiction matrix in order to expand its applicability to typical problems in chemical process industries [12]. And in the context of multiple contradictions a method was structured to assist recognition and classification of contradictions on its impact for marketing communication quality [13]. Compared to the various approaches proposed in literature, a particular attention is dedicated in our work to the Decision-Maker Preferences (DMP) consideration as a crucial element in prioritizing contradictions. By adopting the DMP-based proposed approach, the designer would be able to converge faster to the most relevant design solutions, thus reducing the development time, optimizing development and innovation resources in accordance with the DMP.

The present work is in the preliminary design behavioral phase during which the designer disposes models describing the system behavior, components and its interactions. Thus induced effects at this stage are highlighted. The study generally aims at minimi- 
zing product development cycles often based on the trial-error logic. We propose the TRIZ contradiction matrix use as an innovation support tool, at this phase. The TRIZ theory systematizes the problem-solving process and allows the designer to directly go to the right solutions through its abstraction process. We are interested in this work in the problems formulated as technical contradictions. Generally, for a complex system the establishment of an analysis, formulation and classification process of its technical contradictions, with a view to the efficient exploitation of the contradiction matrix is crucial. The structured approach enables prioritizing a set of technical contradictions via the subjective DMP integration.

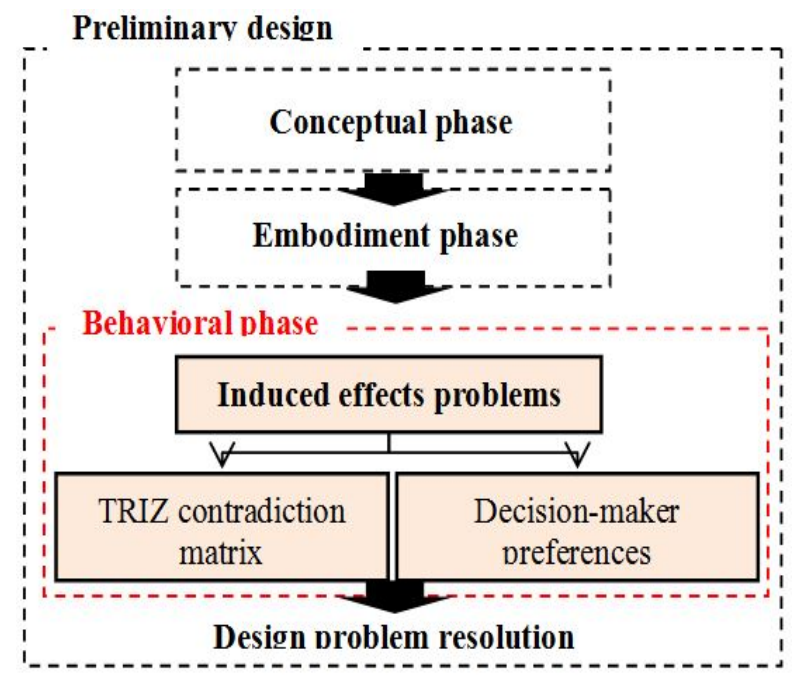

Figure 1. Preliminary design innovation aid methodology

The present work describes an approach for determining the most critical in a multiple contradictions situation. The latter allows evaluating and prioritizing established contradictions in terms of their importance in improving the product while integrating the decision-maker subjective preferences.

The proposed approach is particularly appropriate for high-level complexity design problems with multiple design parameters interaction and several design targets that are often contradictory and heterogeneous.

\section{DECISION-MAKER PREFERENCES INTEGRATION}

For complex systems, the improvement of a parameter often leads to the degradation of several other parameters, and to unwanted induced effects. The problem is then no longer limited to the resolution of a specific contradiction, but to a set of contradictions generated in the system resolving. In this context, we underline the need to classify and prioritize these contradictions in order to direct the designer to solve the most critical problem according to functional specifications. The criticality of the induced effects will depend on the design objectives to be achieved. Contradictions classification in terms of criticality subject to the design objectives would then be crucial and a complementary part to the TRIZ contradiction matrix exploitation; it thus becomes necessary to integrate the DMP.
For this we have been based on the DMP approach proposed by El Amine [14]. First of all, introducing the non-prioritized technical contradictions, the second step is the design problem analysis with respect to the design objectives via the process of integration of the DMP; finally at the output the model presents the prioritized contradictions according to the design objectives satisfaction level. The DMP integrating process is divided into three fundamental models: Observation model, Interpretation model and Aggregation model. The observation model allows formalizing the objective behavior of the corresponding design alternative to a contradiction and does not include any subjective DMP. The subjective preferences of the decision-maker are formalized in the interpretation and aggregation models.

Desirability Functions setting: The parameterization of a desirability function is based on the use of a semantic scale, allowing the decision maker to associate a level of semantic satisfaction with a given value of the desirability indice DI. In 1965, Harrington proposed desirability functions in the field of quality, one of the most commonly used desirability function classes [15] (Figure 2).

Aggregation functions setting: Aggregation is defined as a process of synthesizing all the numerical values resulting from the interpretation, through an aggregation operator, in order to obtain a unique numerical value reflecting the global appreciation of the alternative of studied design called "global desirability indice GDI". The implementation of the aggregation model is done through the choice of the appropriate aggregation operator. Yager [16] proposed the operator GOWA (Ordered Weighted Averaging Operator) which allows a continuous progression of the degree of compensation between the two extreme cases. This operator incorporates a noted parameter 'S', it allows setting the desired compensation degree by the decision maker and the design objectives weight ' $w i$ '. This family of operators is expressed by relation 1 .

$$
\begin{array}{r}
G D I\left(\left(D I_{1}, w_{1}\right), \ldots,\left(D I_{n}, w_{n}\right), s\right)=\sqrt[S]{\frac{\sum_{1}^{n}\left(w_{i}\left(D I_{i}\right)^{s}\right)}{\sum_{1}^{n} w_{i}}} \\
\text { and }\left\{\begin{array}{c}
w_{i} \geq 0 \\
s \in]-\infty,+\infty[
\end{array}, \sum_{i=1}^{n} w_{i}=1 .\right.
\end{array}
$$

We define below the main terms that will be used in this paper.

Design objectives 'DO': formalized on the basis of behavioral models to interpret the state or quality of a design alternative and to compare it against a reference defined by the specifications.

Behavior models: one of the ways to evaluate the performance variables of a design alternative.

Design Parameters 'DPi': Parameters used by the designer to re-design or improve a product.

Environment parameters 'EPi': describe the external environment with which the product will interact. 
Semantic scale

Corresponding to the

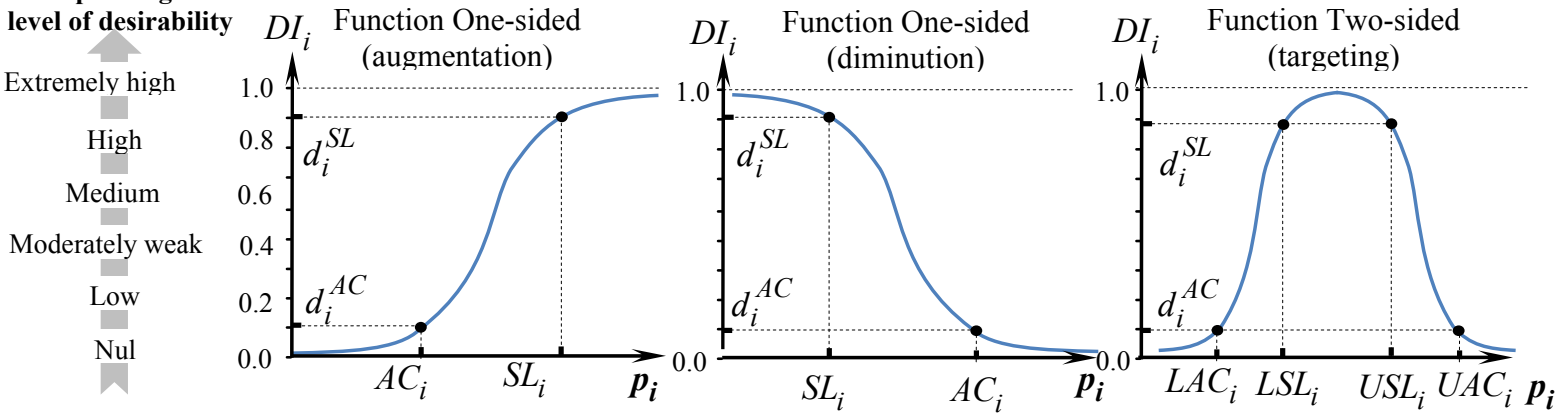

Figure 2. Harrington desirability functions [15]

Performance Variables ' $\boldsymbol{p i}$ ': are used by the designer to describe the behavior of the design alternative being studied, and provide information on the level of satisfaction of the design objectives (cost for example).

TRIZ Engineering Parameters: a list of 39 "generic" design parameters that model the physical quantities that could present contradictions[17].

Induced effects: in the behavioral phase, which characterizes the behavior of the system and its components, appears the induced effects, representing physical phenomena related to functional flows (noise, heaing, rupture, deformation, etc).

\section{PROPOSED APPROACH}

The proposed approach (figure 3), allows identifying and prioritizing inherent contradictions when improving a system performances. This approach is as described based on four essential phases.

\section{PHASE I: Design problem analysis and technical contradictions formulation}

Firstly the designer formulates the need through the behavior models (maximizing, reducing or targeting a value for a design objective). This step will then be used to perform a sensitivity analysis against the model variables in order to specify the parameters to be improved and deteriorated ones. The designer could determine in this step the different induced effects implemented in relation to the deteriorated parameters and their impacts on the design objectives listed in specifications. Finally the formulation of the set of contradictions to solve is established. The second phase of the process focuses on prioritizing these contradictions in order to direct the designer towards the right design alternative and the most relevant contradiction to solve. The diagram presented in Figure 4 illustrates a general overview of the first phase different stages. The latter begins with the expression of the principal design objective (PDO) and goes as far as the setting up of the non-prioritized technical contradictions.

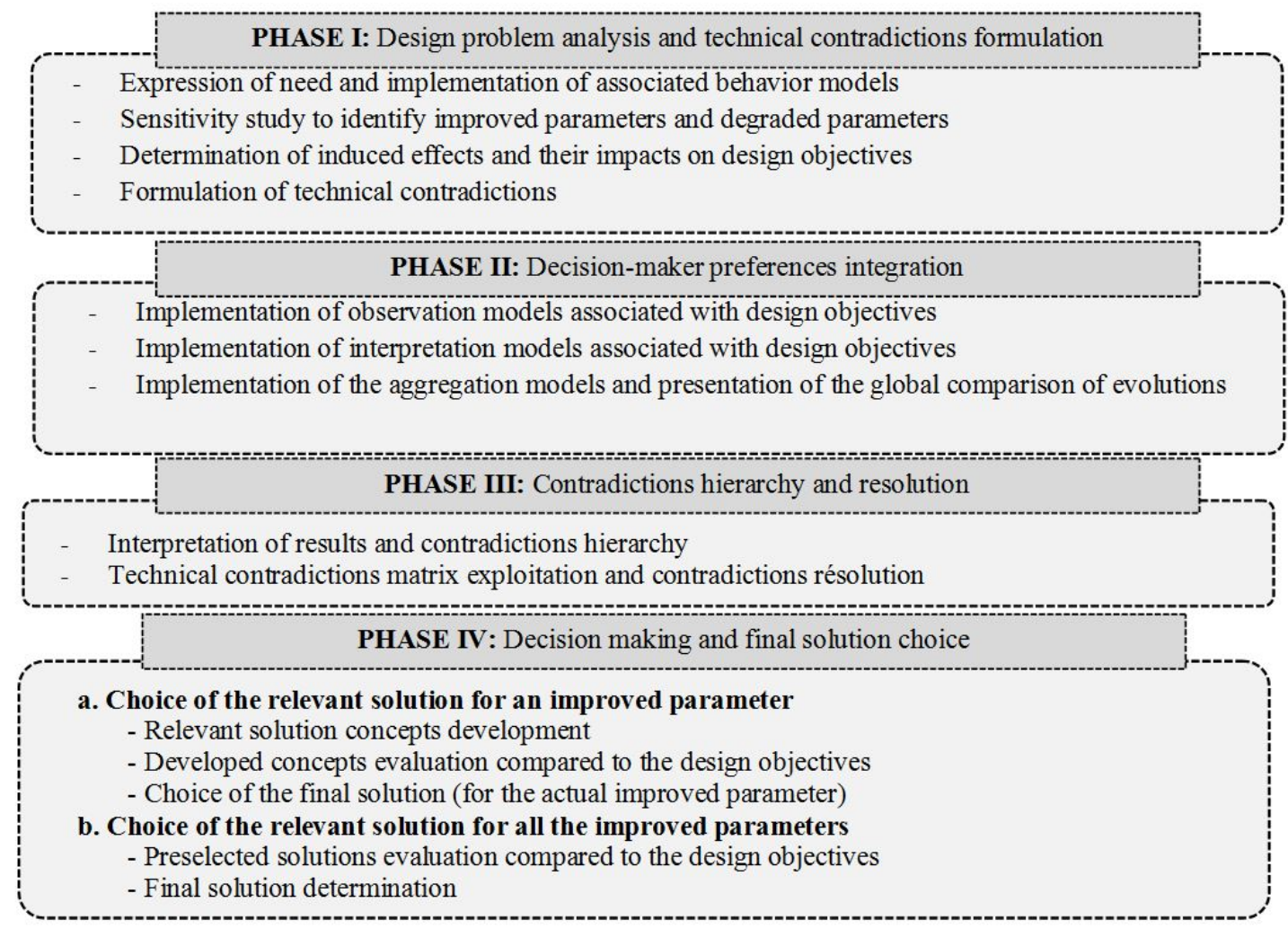

Figure 3. Proposed approach 


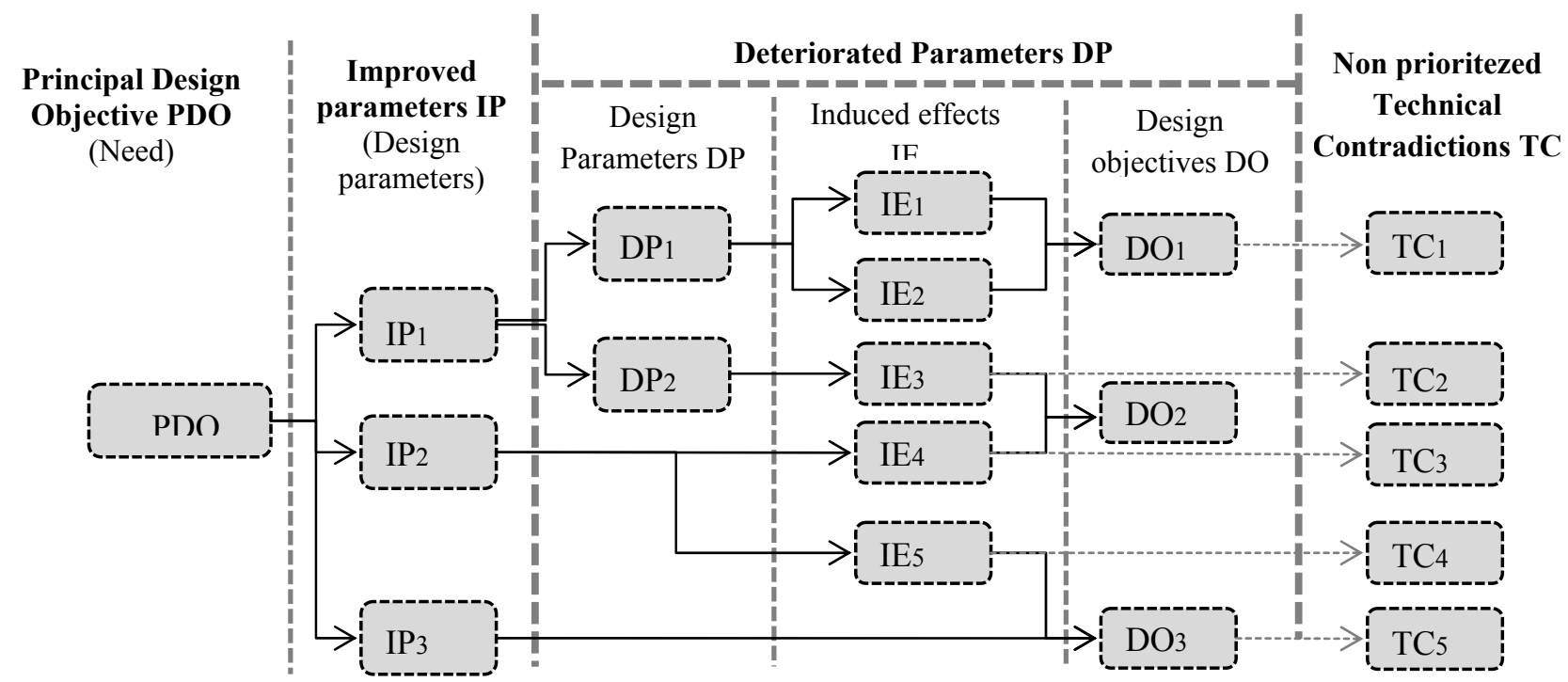

Figure 4. Problem analysis and technical contradictions formulation

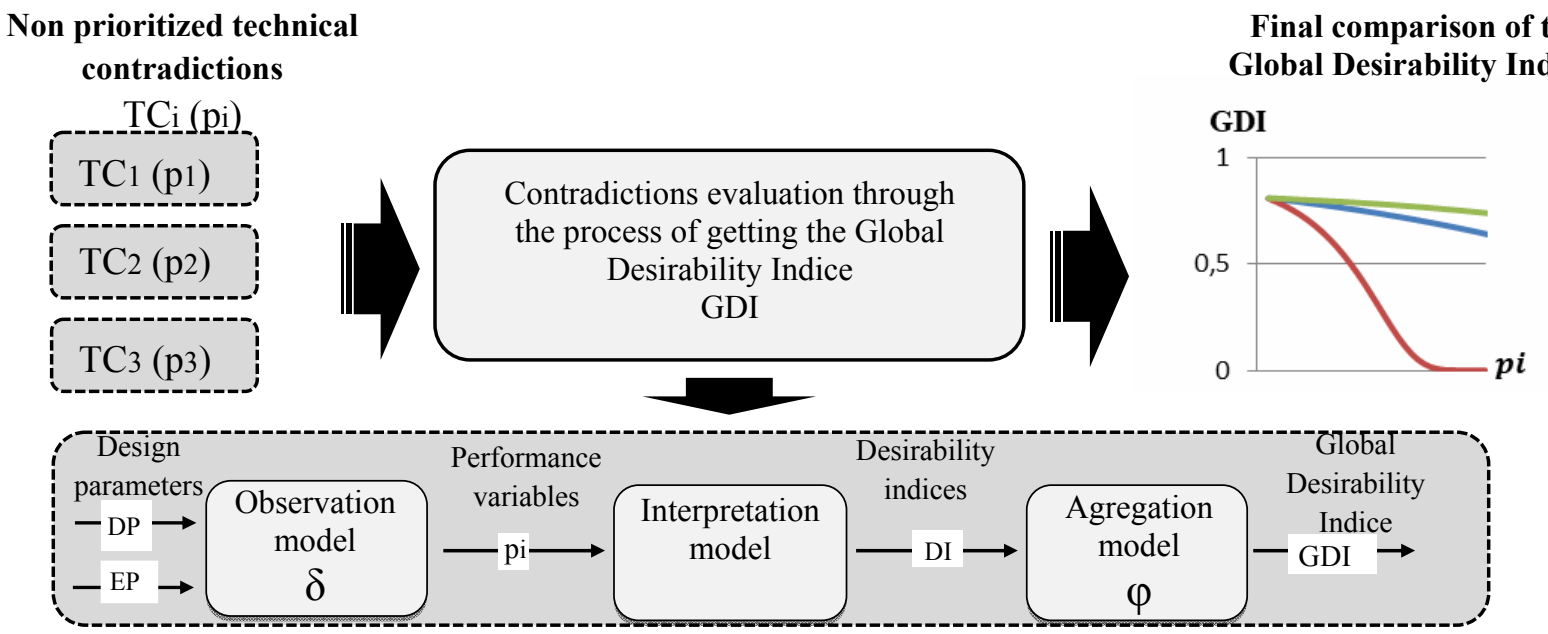

Figure 5. Decision-maker preferences integration

PHASE II: Decision-maker preferences integration The DMP are integrated through observation, interpretation and aggregation models appropriate for the design problem implementation. It is therefore necessary for each model to identify the input and output variables in order to obtain at the end of the process with Global Desirability Indice GDI. The latter allows comparing different design alternatives. As illustrated in the figure 5 , the GDIs obtaining process has in the input perfor-

Non prioritized

Technical Contradictions

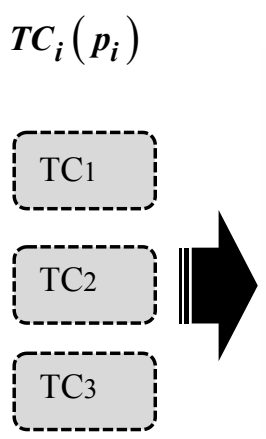

Final comparison of the

GDI

\section{GDI}

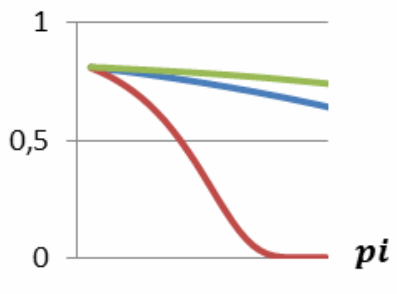

mance variables (pi), among which we distinguish those associated with the technical contradictions representing their deteriorated parameters.

The final comparison of the GDIs informs the designer on the level of satisfaction of the design objectives related to performance variables. Finally, the designer is able to prioritize the technical contradictions through the GDI evolution and their impact on the design objectives.

\section{Prioritized technical contradictions}

Technical Contradictions resolution

$$
T C_{i}^{j}\left(p_{i}\right)
$$

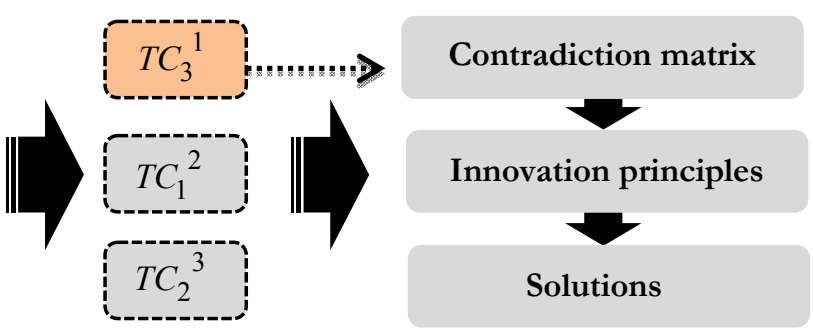

Figure 6. Contradictions hierarchy and resolution 
PHASE III: Contradictions hierarchy and resolution The final comparison of the GDIs, allows in this phase contradictions prioritizing according to their impacts on the design objectives. The designer at this stage compares the different contradictions on the basis of their degradations of the GDI. Then the designer could specify the "deteriorated parameter" which constitutes, with the previously specified "improved parameter", the critical technical contradiction. This degraded parameter is the one associated with the induced effect presenting the most degradation on the GDI. In result, the technical contradictions envisaged are all prioritized (figure 6). Thus the designer is directly oriented towards the good design alternative. The TRIZ contradictions matrix exploitation to resolve technical contradiction specified from the final comparison of the GDIs, presents the penultimate stage of the process. Finally the step of specifying the abstract solutions representing in this approach innovation principles proposed by the technical contradictions matrix [17]. The abstract solutions specification depends mainly on the knowledge, experience and performance of the designer. However, exploiting the patent base and working in multidisciplinary teams can be an important factor simplifying the specification process.

PHASE IV: Decision making and final solution choice This phase is dedicated to the process of final solution specification.

\section{PROPOSED APPROACH ILLUSTRATION ON A WIND SYSTEM}

This section illustrates the proposed approach through a case study on the wind system. The problem resolving through the integration of desirability functions, aggregation models and the TRIZ matrix exploitation is developed according to the proposed approach different phases.

\subsection{Phase I: problem analysis and formulation of technical contradictions}

Need expression-Principal Design Objective specification: In this case study, the principal design objective is to maximize the power of a large wind turbine type Vestas $90 / 2 \mathrm{MW}$ [18], from its initial power of $325 \mathrm{Kw}$ to $425 \mathrm{Kw}$ value specified by the decisionmaker (Figure 7). We note that the initial power is that of the current version of the wind turbine considered. This power takes into consideration the initial technical and environmental characteristics of the initial wind turbine studied version.

Wind system power model: The power model allows identifying power maximization of different alternatives acting on design parameters and evaluating power sensitivity due to the design parameters. Being based on the wind system power model (formula 2) the power maximization is possible by acting on the main design parameters: Power coefficient ' $C P$ ', rotor section ' $A$ ' related to the blade length 'Lblade' and speed at the rotor height function of tower length ' Ltower'.

$$
\begin{gathered}
P=\frac{1}{2} \rho C_{P} A V^{3} \eta_{m} \eta_{g} . \\
A=\pi R_{r}^{2} .
\end{gathered}
$$

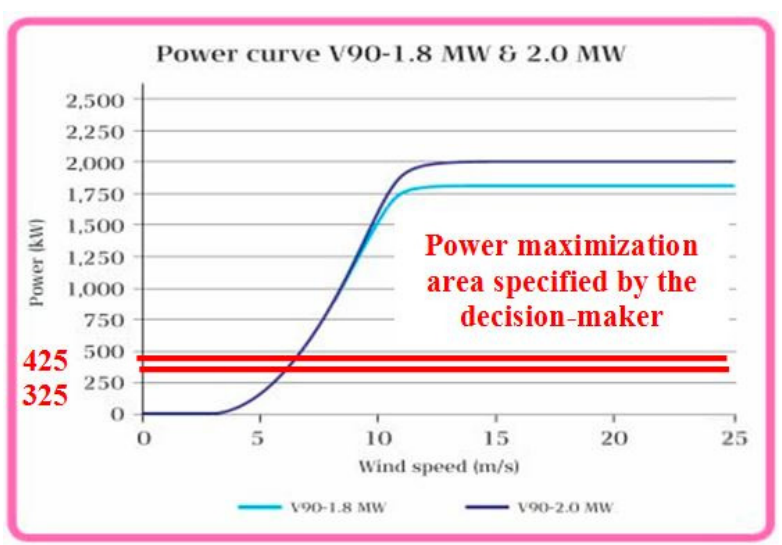

Figure 7. Power maximization objective targeted [18]

We present in Table 1 the different characteristics and parameters of the considered power model.

Table 1. Variables and characteristics of the power model

\begin{tabular}{|c|c|c|c|}
\hline Symbol & Signification & $\begin{array}{c}\text { Associated } \\
\text { value }\end{array}$ & Unit \\
\hline$\rho$ & Air density & 1.224 & $\mathrm{Kg} / \mathrm{m}^{3}$ \\
\hline$C p$ & Power coefficient & 0.5 & --- \\
\hline$R$ & $\begin{array}{c}\text { Surface swept by } \\
\text { the blades }\end{array}$ & $\begin{array}{c}\text { Varies with } \\
\text { blade's length }\end{array}$ & $\mathrm{m}^{2}$ \\
\hline$V$ & $\begin{array}{c}\text { Rotor radius, Blade } \\
\text { length }\end{array}$ & variable & $\mathrm{m}$ \\
\hline$\eta_{m}$ & $\begin{array}{c}\text { Wind speed at the } \\
\text { considered site }\end{array}$ & $\begin{array}{c}\text { Varies with the } \\
\text { tower high }\end{array}$ & $\mathrm{m} / \mathrm{s}$ \\
\hline$\eta_{g}$ & Generator yield & 0.82 & --- \\
\hline
\end{tabular}

Sensitivity study on the parameter: After expressing the need and implementing the associated behavior model, the design problem analysis, is carried out through a parametric analysis based on identification of the main problem resolution alternatives. (Maximizing the power of the wind turbine in our case, by acting on its design parameters). This first step of parametric analysis focuses on the determination of "improved parameters" and associated "deteriorated parameters" to formalize technical contradictions. Then, we proceed to the specification of the induced effects in relation with the set of the deteriorated parameters. The last step in this analysis process is to link the deteriorated parameters to the design objectives through the induced effects. The wind system power maximization problem analysis is shown schematically in Figure 8 below.

Formulation of established technical contradictions: The problem analysis illustrated in Figure 8 specifies the three design parameters that the designer can act on to maximize power. According to the power model, this maximization is related to the increase of three design parameters: The power coefficient $C p$ which characterizes the blade shape, the section $A$ swept by the rotor (corresponding to the increase of the length of the blades) and the increase in the tower length which is in relation with the wind speed. In this study we will 
be interested only in the two parameters Blades length and Tower length to reach the design objective intended by the decision-maker. The power coefficient $C p$ is not considered, given the maturity reached in the industrial sector in aerodynamic optimization of the blade shape. The improvement of the considered parameters implies the degradation of other parameters in relation. The set of technical contradictions that characterize the problem integrates each pair "Improved Parameter, Deteriorated Parameter". The standard expression of the adopted technical contradictions is presented in table 2 .

To formulate these contradictions, the designer must associate parameters expressing the problem (design parameters, performance variables, induced effects or design objectives) with the 39 TRIZ engineering parameters. Thus, each formulated technical contradiction corresponds to one or more induced effects. In this problem analysis we have established from the degraded parameters the different corresponding induced effects. These latter were subsequently related to the specified design objectives.

\subsection{PHASE II: Decision-maker preferences integration}

\section{- Observation model}

The wind system behavior is formalized through observation models, allows having a quantitative indicator of the induced effects. These can then be interpreted using desirability functions [15], to evaluate their impact on the design objectives, namely, in our case of study, the wind system cost and the aerodynamic noise. We will present in the following, for the three technical contradictions, the observation models and the evolutions of the design objectives according to performance variables.
Technical contradiction 1: System cost/Blade length: In order to approximate the wind system cost variation due to the blade and tower length increase, we have been interested to all system components with considerable cost. The selection was made by referring to the actual wind system components cost presented by Wind pact [19].

Cost variation with blade's length increase: The graph in Figure 9 shows the wind system cost variation due to the blade length increase. The wind system approximated costs considered in this study, is equal to the sum of the selected components cost's. In this study, we neglected the effect of blade surface variation due to increasing their length on the component dimensioning. This simplification is implemented because, the analytical models that allows determining the cost according to the design parameters, shows a small variation of components cost with the increase of the blades surface.

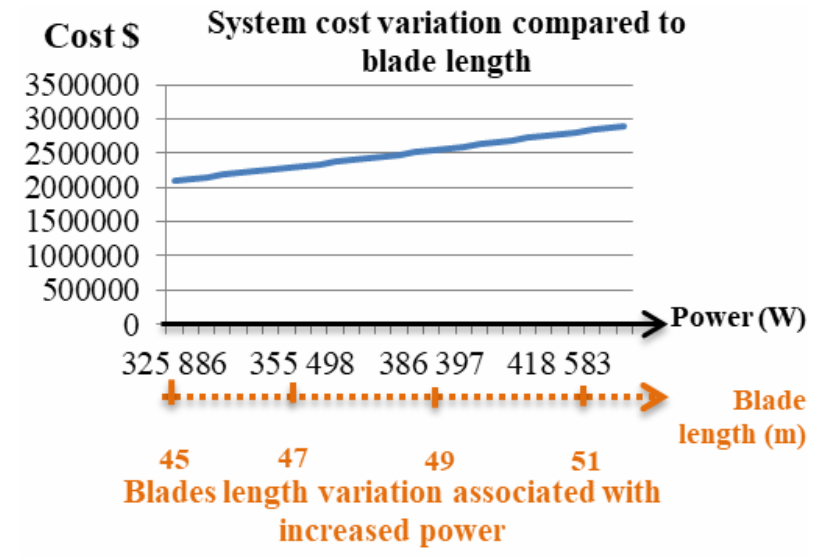

Figure 9. Wind system cost variation with blade's length increase

Table 2. Standard expression of technical contradictions

\begin{tabular}{|c|c|c|c|c|}
\hline Improved parameter & Deteriorated parameter & Induced effect & $\begin{array}{c}\text { Design objectives affected } \\
\text { by induced effects }\end{array}$ & Contradictions \\
\hline $\begin{array}{c}\text { Static object length (blade } \\
\text { length) }\end{array}$ & $\begin{array}{c}\text { Static object mass } \\
\text { (System mass) }\end{array}$ & Components damage & Wind system cost & TC1 \\
\cline { 2 - 5 } & Speed & Aerodynamic noise & Aerodynamic noise & TC2 \\
\hline $\begin{array}{c}\text { Static object length (tower } \\
\text { height) }\end{array}$ & $\begin{array}{c}\text { Static object mass } \\
\text { (Tower mass) }\end{array}$ & -------- & Wind system cost & TC3 \\
\hline
\end{tabular}

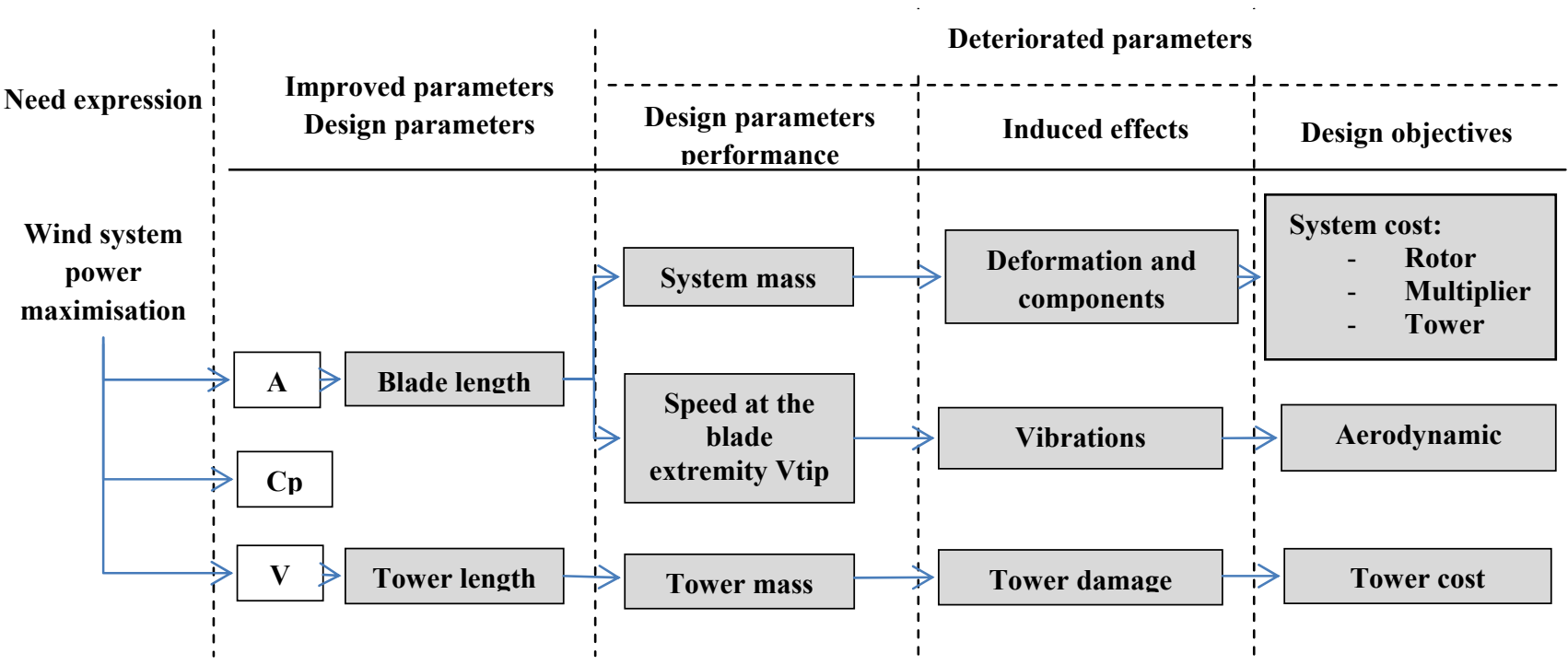

Figure 8. Parametric problem analysis 
Technical contradiction 2: Noise/Blade length: Aerodynamic noise is the most wind systems considered environmental aspect. Considered as a harmful induced effect generated by the rotation of the blades. The noise is proportional to the speed at the end of the blade, which is expressed as a function of the blade length. As the blade length corresponds to the rotor radius, the latter is related to the noise model according to Wagner with the formula (4), [20].

$$
\begin{gathered}
L_{w}=10 \log \left(\frac{\pi D_{r}^{2}}{4}\right)+50 V_{t i p}-4 . \\
V_{\text {tip }}=\frac{\pi N_{r} D_{r}}{60} .
\end{gathered}
$$

The table 3 below gives the parameters of the aerodynamic noise model considered.

Table 3. Variables of the aerodynamic noise model

\begin{tabular}{|c|c|c|c|}
\hline Symbol & Signification & $\begin{array}{c}\text { Associated } \\
\text { value }\end{array}$ & Unit \\
\hline$L w$ & Aerodynamic noise & Variable & $\mathrm{Db}$ \\
\hline$N_{r}$ & Rotor rotational speed & 17 & $\mathrm{Tu} / \mathrm{min}$ \\
\hline$D_{r}$ & Rotor diameter & Variable & $\mathrm{m}$ \\
\hline$V_{t i p}$ & $\begin{array}{c}\text { Speed at the end of the } \\
\text { blade }\end{array}$ & Variable & $\mathrm{m} / \mathrm{s}$ \\
\hline
\end{tabular}

Aerodynamic noise variation with blade's length increase: The graph in Figure 10, shows the wind system noise variation due to the necessary increase in blade length to achieve the power maximization goal targeted.

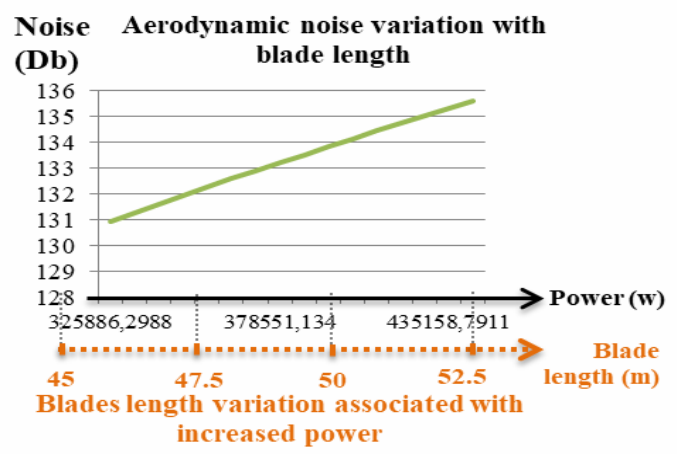

Figure 10. Aerodynamic noise variation with blade length increase

Technical contradiction 3: System cost /tower length: We will present in this part the system cost variation, according to the increase of the tower length to reach the goal of maximization of targeted power. In fact, the increase in tower highly contributes to the maximization of the power of the wind turbine through the variation of the wind speed with the height on the ground. In this sense, we have adopted the model of variation of the speed of the wind according to the height with the ground which corresponds to the tower length in this application.

Speed variation with tower length increase: In our case study, we adopted the following model of wind speed variation, according to the height from the ground:

$$
V(h)=V_{0}\left(\frac{h}{h_{0}}\right)^{\alpha} .
$$

With: $V:$ Wind speed at a height $h ; V_{0}$ : Wind speed measured at a height $h_{0} ; \alpha$ : shear coefficient. We recall that the environmental conditions are taken equal to those used for calculating the initial performance of the wind turbine before modification. The characteristics of the selected site are summarized in Table 4 below:

Table 4. Wind speed variation model variables

\begin{tabular}{|c|c|c|c|}
\hline Site type & $V_{0}(\mathrm{~m} / \mathrm{s})$ & $h_{0}(\mathrm{~m})$ & $\alpha$ \\
\hline II (EC) & 4,4 & 10 & 0,157 \\
\hline
\end{tabular}

Wind system cost variation with tower length increase: The wind speed variation model expressed by formula 6 allows deducing the following formula which presents the height as a function of the wind speed (formula 7):

$$
h(V)=h_{0}\left(\frac{V}{V_{0}}\right)^{\frac{1}{\alpha}} .
$$

From this formula, we first determined the evolution of the speed necessary to reach the specified power target. Then, we deduced the corresponding variation of height (tower length) to reach the objective of speed and thus of power (Power and speed linked by the model of power). At the end, the system cost was calculated. The graph in Figure 11 shows the wind system cost variation due to the tower height increase to reach the specified power maximization target. The approach, in this case, takes into account only the additional cost due to the increase in the tower height. The cost of other components redesign due to the increase in wind speed, in this case, remains unchanged (the performance of most of the current components are compatible with the increase in the speed envisaged).

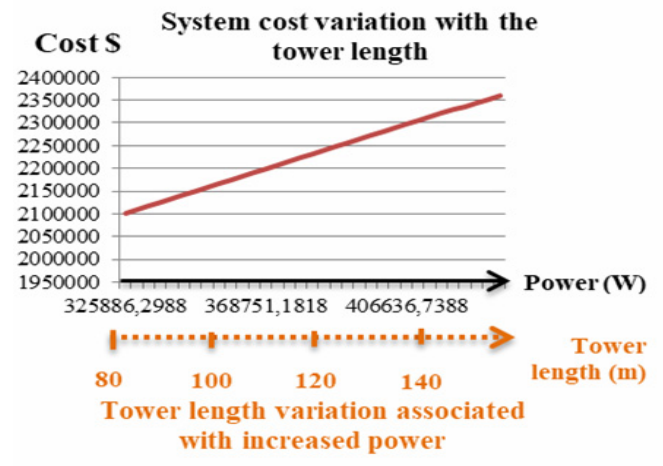

Figure11. System cost variation with the tower length

\section{- Interpretation model}

At this stage, we have the power increase impact on the different design objectives. However, it is necessary to consider the decision-maker subjective preferences according to each design objective. We will detail in the following paragraphs, the DMP integration through the desirability and aggregation functions. 

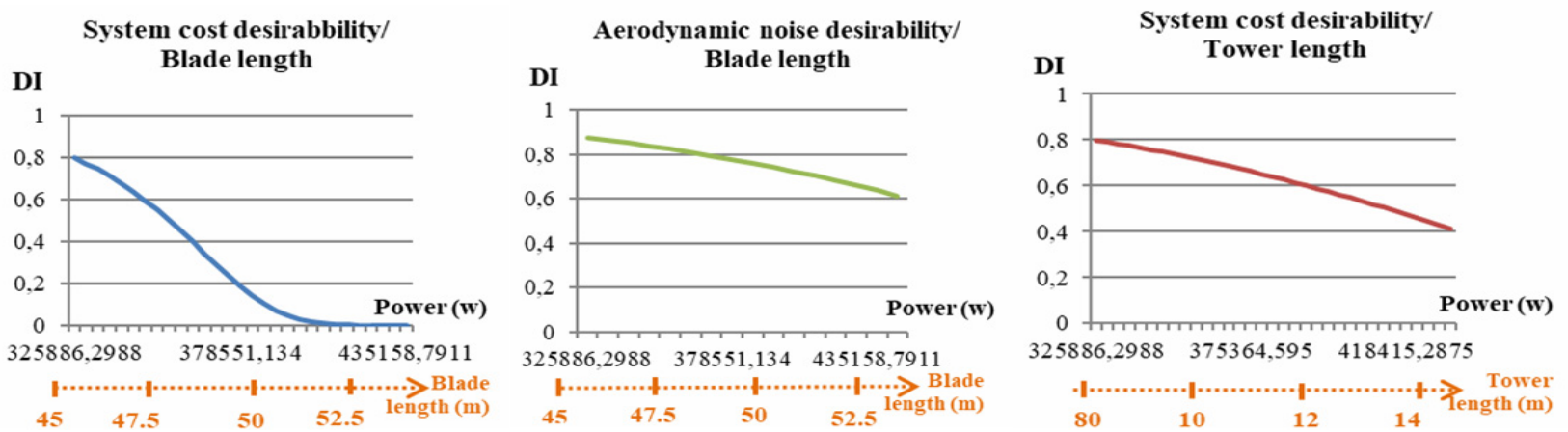

Figure 12. Desirability variation for the three design objectives

Desirability functions setting: In our case study, for a type II site (lakes or flat and horizontal zone with negligible vegetation and free of all obstacles according to the Eurocode [21]), sufficiently far removed from the inhabited zone we associated desirability 0.9 to $130(\mathrm{~dB})$ and 0.2 to $140(\mathrm{~dB})$. For the economic aspect in relation to the wind system considered cost, we associated a good desirability 0.8 to a cost close to the current version cost (Tower height $=80 \mathrm{~m}$ and Blade length $=90 \mathrm{~m}$ ) which is equal to $\$ 2100000$. A low desirability 0.16 has been associated to a system cost equal to $\$ 2500000$. The desirability associated values do not represent unique choices. The decisionmaker can associate other different values according to the constraints. The assignment of the different values that define the desirability functions depends on the industrial context, the budget initially allocated to the project, the project manager and the standards that often present references for the decision-maker. The specification of the final values results from consultation between all the project actors. The parameterization of desirability functions adopted for the calculation is presented in Table 5 .

Table 5. Desirability functions setting

\begin{tabular}{|l|c|c|c|}
\cline { 3 - 4 } \multicolumn{2}{c|}{} & \multicolumn{2}{c|}{ Design objectives } \\
\cline { 3 - 4 } \multicolumn{2}{c|}{} & System cost (\$) & $\begin{array}{c}\text { Aerodynamic } \\
\text { noise (db) }\end{array}$ \\
\hline \multirow{2}{*}{ Point 1 } & $d_{i}^{S L}$ & 0.8 & 0.9 \\
\cline { 2 - 4 } & $S L_{i}$ & 2100000 & 130 \\
\hline \multirow{2}{*}{ Point 2 } & $d_{i}^{A C}$ & 0.16 & 0.2 \\
\cline { 2 - 4 } & $A C_{i}$ & 2500000 & 140 \\
\hline
\end{tabular}

The graphs shown in Figure 12 illustrate the three considered design objectives desirability degradation function of related design variables (Lblade and $h$ ) variation when reaching the power objective target. Transition from actual values of design objectives to adimensional desirability values allows considering the DMP and visualizing evolutions on the same scale. However, the latter are not comparable because the desirability indices correspond to the different design objectives. In order for these evolutions to be comparable, their impacts on the overall system desirability has to be considered. Thus we use the aggregation model that makes these objectives comparable considering the relative importance ' $w i$ ' assigned to each objective, and the value of the parameter ' $S$ ' representing compensation degree desired by the decisionmaker.

Aggregation function setting: In this part, we associate to the previously obtained desirability indices, a Global Desirability Indices, allowing to inform on the GDI degradation function of the performances variables variation. Thus, the evolutions of the three specified design objectives will be comparable. Yager's adopted aggregate operator [16] proposes to assign weights to the different design objectives whose sum is 'one', plus the determination of the value of the compensation parameter 's' according to the adopted design strategy. We recall that a negative value of this compensation parameter is associated with a compensating design strategy [14]. The table 6 shows the values defined for the setting of our aggregation function.

Table 6. Agregation functions setting

\begin{tabular}{|c|c|c|}
\cline { 2 - 3 } \multicolumn{1}{c|}{} & $\begin{array}{c}\text { Aerodynamic } \\
\text { noise }\end{array}$ & System cost \\
\hline Ponderation 'wi' & 0.3 & 0.7 \\
\hline Compensation 's"s' & \multicolumn{2}{|c|}{-0.7} \\
\hline
\end{tabular}

After calculating the global desirability indices corresponding to desirability indices through the desirability function, we plotted the final comparison of the GDIs for the three design objectives (Figure 13). Each curve in the graph represents a technical contradiction. To obtain the curve associated with a contradiction, we set the initial value of the design objective and its corresponding desirability indice to the original value (of the initial version) and we only change the affected objective (s). For example, for the improved blade length parameter that influences the cost and the noise, when we want to trace the GDI evolution curve of the noise, we start from the corresponding GDI to the initial version and then, by varying the length of the blades, we evaluate the degradation of the induced effect "Noise" only on the GDI (The induced effect due to the increase of the mass is not considered / we suppose that the mass remains constant). Exploiting this result will classify the set of contradictions in terms of their impacts on the design objectives while considering the preferences of the decision-maker.

After calculations, we obtained the results of figure 13. That enables classifying the set of contradictions in terms of their impacts on the overall design objective, 
expressed by the GDI while considering the preferences of the decision-maker.

We present in the following the aggregation model adopted in our case and the final comparison of design objectives based on the Global Desirability Indice GDI.
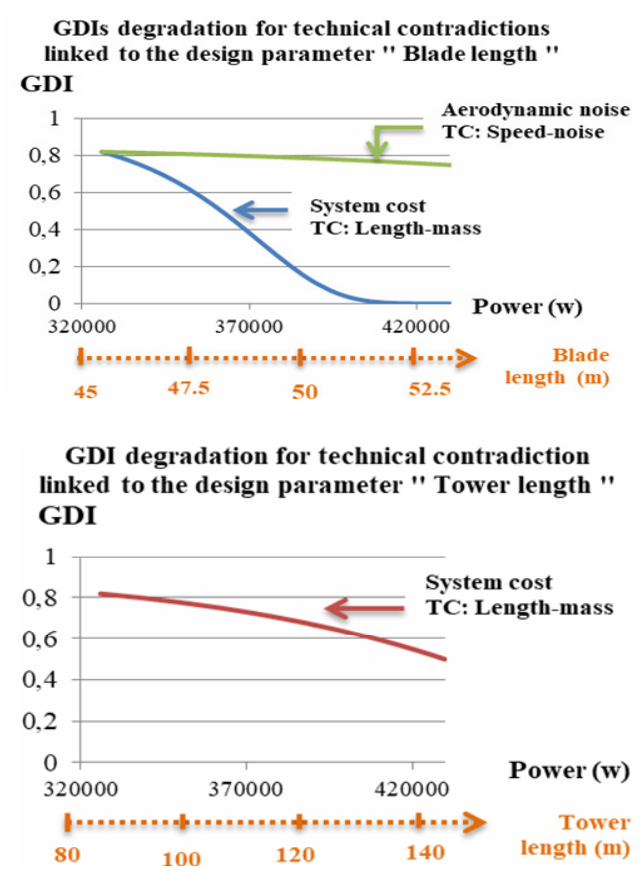

Figure 13. Global desirability indice evolution compared to the design objectives

\subsection{PHASE III: Contradictions hierarchy and resolution}

Results interpretation and contradictions hierarchy:

Consider the technical contradictions Associated with the improved "blade length" parameter, the most critical contradiction to resolve is the contradiction
(Length-mass). In fact, it is the one that presents more degradation of the GDI (figure 14).

The problem to solve concerns the technical contradiction "Blade length-System mass". At this point, and in order to minimize the weight of the wind system, we focused on reducing the weight of the multiplier component, the most important component in the nacelle. The contradictions to be solved then is: "Blades length - Multiplier mass"

\section{TRIZ CONTRADICTION MATRIX EXPLOITATION AND SPECIFIED CONTRADICTION RESOLUTION}

According to the final comparison of the GDIs, the maximization of the power of the wind system through the variation of the blade length is considered the most adequate with the design objectives because it induces the least degradation on the GDI.

We are now interested to solving the problem as a contradiction related to the blade length variation. The standard formulation of the specified contradiction is:

- $\quad$ Improved parameter $\rightarrow$ Static object length

- $\quad$ Deteriorated parameter $\rightarrow$ Static object mass

The exploitation of the matrix of contradictions proposes for the indicated parameters four innovation principles $(35,28,40,29)$ in figure 15 . The exploration of the different principles directs the designer towards the following concepts of solutions.

Solution 1 "Topologically optimized transmission": Directives of principle 35 investigation: "modification of parameters", orient to think following the instruction "Change the concentration or the consistency" to a more optimized form of the gears. Thus, we opt for reducing the multiplier mass by optimizing the gears mass with topological optimization. This solution changes material concentration in non-functional area, while respecting the resistance constraints.

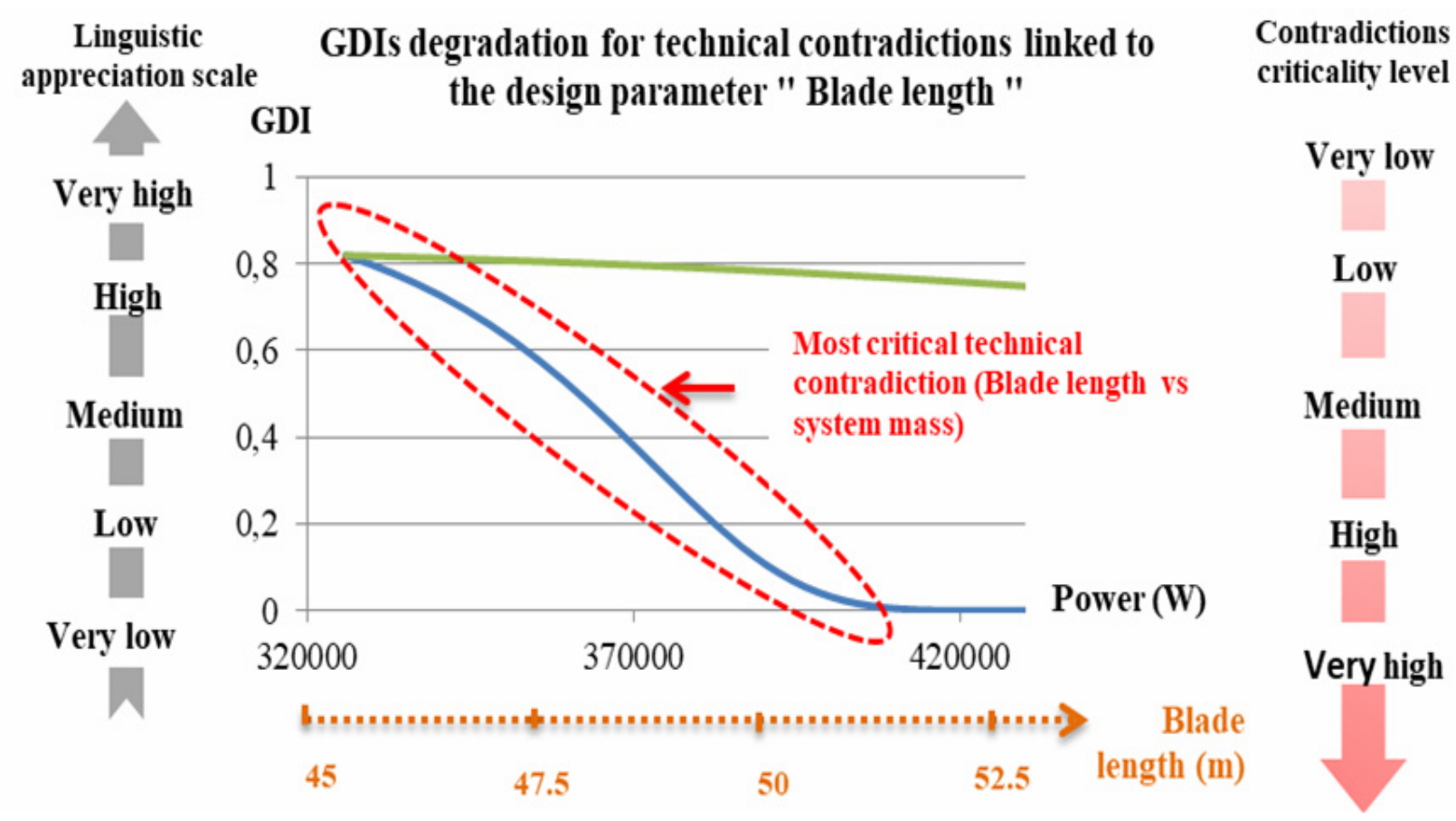

Figure 14. GDIs degradation for technical contradictions linked to the design parameter " Blade length " 


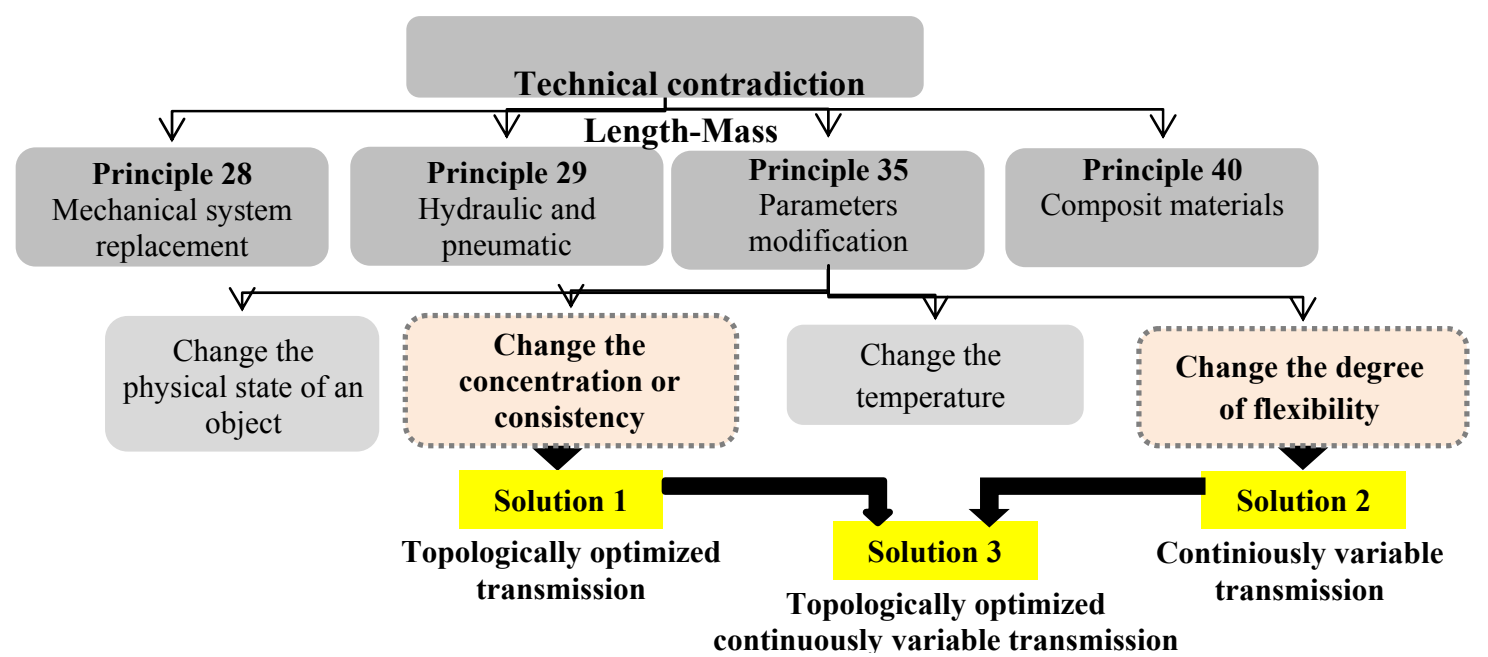

Figure 15. Solutions concepts proposal tree

Solution 2 "Continiously variable transmission": Principle 35: "Modification of parameters - Modifying the degree of flexibility", guides the designer to solve the specified problem modifying flexibility degree to reduce the system mass. This is explained by the oversizing of systems with a low flexibility degree. Therefore, we propose as a solution to replace the reference multiplier type "planetary three-stage with fixed ratio", by a continuously variable transmission.

Solution 3 "Topologically optimized continuously variable transmission": This third proposed solution results from the combination of the first and the second solution. We propose to replace the reference multiplier by a continuously variable transmission whose gears are topologically optimized. This solution will combine the advantages of the first and second solutions for maximum gain in mass.

We note that at this stage the process of generating concepts is part of an organized design activity, based on brainstorming ideas during which, the designers together can exploit some of Altshuller's tools for unlocking psychological inertia to promote the ideation spirit and foster creativity.

\subsection{PHASE IV: Decision making and relevant solutions choice}

To select the appropriate solution, all proposed solution concepts should be developed and evaluated against the design objectives (Cost and noise for our application case). At this stage, it is important to have pre-selection tools to distinguish the most relevant solutions, in order to minimize development in terms of human resources and processes. The "PSNP-Parallel Set Narrowing Process" can be adopted as a basic tool for decision support and choice of relevant concepts at this stage. The process allows a several concepts parallel development until a sufficient knowledge level is available to permit the most relevant concept selection. The optimal solution obtaining process structuring is crucial at this stage.

\subsection{Harmonization aspect consideration in a design project}

A product generally represents an elementary component of a more complete system (The wind system stuFME Transactions died, which is part of the complete "wind farm" system). Thus, design choices associated with the developed object may have an impact on other components and design activities associated with the overall system [22]. In the presented study, the multiplier-related design choices mainly affect the possibility of increasing the wind turbine blades length that impacts the wake effect on the turbines positioning (wind farm optimization) $[23,24]$. In the present paper, these considerations have not been integrated. An interesting perspective is to adapt our approach to integrate inherent interactions in a whole development projects. For this, the designer must be able, firstly, to highlight the interactions between different parts of the system and, secondly, to assess the impact of elementary decisions on the overall project target.

\subsection{CONCLUSION}

Survey results show the advantage of exploiting TRIZ in the design field [2]. It should be noted that TRIZ does not give innovations and does not solve the problem directly but directs the designer towards the most promising solution, comparing TRIZ's abstract solutions to technical industrial reality. However, TRIZ tools often present operation difficulties for users. In this context several attempts to formalize TRIZ tools have been implemented. In an increasingly collaborative development environment, this formalization provides a favorable framework for communication and exchange between project stakeholders. In complementarity with these works we presented in this paper a design approach aiming at the TRIZ contradiction matrix formalization. This tool has widely been used to enhance innovation spirit in many fields. Yet the exploitation of the contradiction matrix presents limits for complex systems. Generally, the improvement of a complex system performance acting on its design parameters induces deterioration of several other parameters, and then the designer must evaluate and prioritize established contradictions according to the criticality level. In this case, contradictions' prioritizing in terms of the criticality related to the induced effects, and with respect to the design objectives, is crucial. In this context, the presented work aimed at 
combining the TRIZ matrix with the DMP integration process to prioritize contradictions. The structured hybrid approach allows innovative design problems resolving especially induced effect problems characterizing the preliminary design behavioral phase as illustrated through the case study on the wind turbine.

\section{REFERENCES}

[1] Altshuller, G., Al'tov, G., \& Altov, H. And suddenly the inventor appeared: TRIZ, the theory of inventive problem solving. Technical Innovation Center, Inc., 1996.

[2] Hmina, K., Sallaou, M., Ait Taleb, A., Lasri, Larbi.: TRIZ The theory of Inventif Problem Solving State of the art. 5th International Conference on Optimization and Applications (ICOA) (pp. 1-7). IEEE., 2019.

[3] Dubois, S. Contribution à la formulation des problèmes en conception de systèmes techniques. Etude basée sur la TRIZ (Doctoral dissertation, INSA de Strasbourg, 2004.

[4] Yamashina, H., Ito, T., \& Kawada, H: Innovative product development process by integrating QFD and TRIZ. International Journal of Production Research, 40(5), 1031-1050, 2002.

[5] Cascini, G., Rissone, P.: Plastics design: integrating TRIZ creativity and semantic knowledge portals. Journal of engineering design, 15(4), 405-424, 2004.

[6] Hua, Z., Yang, J., Coulibaly, S., \& Zhang, B.: Integration TRIZ with problem-solving tools: a literature review from 1995 to 2006. International Journal of Business Innovation and Research, 1(12), 111-128, 2006.

[7] Li, M., Ming, X., Zheng, M., Xu, Z., \& He, L.: A framework of product innovative design process based on TRIZ and Patent Circumvention. Journal of Engineering Design, 24(12), 830-848, 2013.

[8] Mayda, M., Börklü, H. R.: An integration of TRIZ and the systematic approach of Pahl and Beitz for innovative conceptual design process. Journal of the Brazilian Society of Mechanical Sciences and Engineering, 36(4), 859-870, 2014.

[9] Hmina, K., Sallaou, M., Arbaoui, A., \&Lasri, L.:A preliminary design innovation aid methodology based on energy analysis and TRIZ tools exploitation. International Journal on Interactive Design and Manufacturing (IJIDeM), 1-10, 2018.

[10] Bhatnagar, R. M.: Case studies for the application of least common multiple (LCM) algorithm for resolving multi-parameter contradiction by inversion of TRIZ contradiction matrix. Journal of the Brazilian Society of Mechanical Sciences and Engineering, 41(4), 162, 2019.

[11] Murakami, T.: Knowledge Management for Problem Solving Using Semistructured Contradiction Matrix Based on Physical Quantity Description. In Proceedings of the Design Society: International Conference on Engineering Design (Vol. 1, No. 1, pp. 1983-1992). Cambridge University Press, 2019.
[12] Pokhrel, C., Cruz, C., Ramirez, Y., Kraslawski, A.: Adaptation of TRIZ contradiction matrix for solving problems in process engineering. Chemical engineering research and design, 103, 3-10, 2015.

[13] Majchrzak, J., Chuda, A., Kalemba, A., \& Weber, G. W.: The Concept of Contradiction Finding and Classification in the Field of Marketing Communication Quality Management. In International TRIZ Future Conference (pp. 438457). Springer, Cham, 2019.

[14]El Amine, M.: Intégration de la maturité des connaissances dans la prise de décision en conception mécanique: application à un système solaire (Doctoral dissertation, Ecole nationale supérieure d'arts et métiers-ENSAM), 2015.

[15] Harrington, E. C.: The desirability function. Industrial quality control, 21(10), 494-498, 1965.

[16] Yager, R. R.: On ordered weighted averaging aggregation operators in multicriteria decisionmaking. IEEE Transactions on systems, Man, and Cybernetics, 18(1), 183-190, 1988.

[17] http://www.triz40.com/TRIZ_Fr.php

[18] http://pdf.directindustry.com/pdf/vestas/v90-1820-mw-brochure/20680-53606.html

[19] Fingersh, L., Hand, M., \& Laxson, A.: Wind turbine design cost and scaling model (No. NREL /TP-500-40566). National Renewable Energy Lab. (NREL), Golden, CO (United States), 2006.

[20] Wagner S., Bareiss R., Guidati G.: Wind Turbine Noise, EUR 16823. ISBN 3-540-60592-4. pp. 8084, 1996.

[21] public.iutenligne.net-Efforts climatiques, Effets du vent

[22] Rašuo, B., Dinulović, M., Veg, A., Grbović, A., \& Bengin, A.: Harmonization of new wind turbine rotor blades development process: A review. Rene -wable and Sustainable Energy Reviews, 39, 874882,2014

[23] Rašuo, B. P., Bengin, A. Č.: Optimization of wind farm layout. FME Transactions, 38(3), 107-114, 2010

[24] Rašuo, B., Bengin, A., \& Veg, A.: On aerodynamic optimization of wind farm layout. PAMM, 10(1), 539-540, 2010.

\section{NOMENCLATURE}

$\begin{array}{ll}\mathrm{Cp} & \text { Power coefficient } \\ \mathrm{Dr} & \text { Rotor diameter } \\ \text { Lblade } & \text { Blade length } \\ \mathrm{Lw} & \text { Aerodynamic noise } \\ \mathrm{Nr} & \text { Rotor rotational speed } \\ \mathrm{V} \text { tip } & \text { Speed at the end of the blade } \\ \mathrm{DI} & \text { Desirability indice } \\ \mathrm{DMP} & \text { Decision-maker preferences } \\ \mathrm{DO} & \text { Design objectives } \\ \mathrm{DO} & \text { Design objective } \\ \mathrm{DP} & \text { Design parameters } \\ \mathrm{DP} & \text { Deteriorated parameter } \\ \mathrm{Dr} & \text { Rotor diameter } \\ \mathrm{EP} & \text { Environment parameter }\end{array}$


GDI Global desirability indice

$\mathrm{h} \quad$ Tower length

IE Induced effect

IP Improved parameter

$\mathrm{Mr} \quad$ Machine rating

PDO Principal design objective

$\mathrm{Pi} \quad$ Performance variables

$\mathrm{Rr} \quad$ Rotor radius

$\mathrm{S} \quad$ Compensation parameter

TC Technical contradiction

A Surface swept by the wind system blades

V Wind speed at the considered site

\section{Greek symbols}

$\delta \quad$ Observation model

$\varphi \quad$ Interpretation model

Aggregation model

$\rho \quad$ Air density

$\eta_{m} \quad$ Multiplier efficiency

$H_{g} \quad$ Generator efficiency

$\alpha \quad$ Shear coefficient

wi Design objectives weight

\section{К. Хмина, М. Ел Амин, Л. Ласри, М. Салау}

Показало се да је ТРИЗ теорија ефикасна за решавање проблема креативности код дизајна производа. Међутим, примена њених различитих алата и техника и даље је отежана онима који нису стручњаци. Опште узев, теорија не нуди потребне алате за подршку проблему моделирања у предпроцесним фазама. У том смислу, многа истраживања имају за циљ да открију како да се олакша коришћење ТРИЗ матрице контрадикције.

Овај рад се бави проблемом тешкоћа коришћења ТРИЗ матрице контрадикције и даје предност техничким контрадикцијама у сложеном систему. Приоритетне техничке контрадикције се утврђују евалуацијом индукованих ефеката на различите одређене циљеве дизајна. Предложени приступ омогућава анализирање и структурирање проблема дизајна у циљу решавања проблема коришћењем ТРИЗ матрице контрадикције.

Предложени приступ даје одговор на главне проблеме настале приликом коришћења матрице, нарочито проблеме везане за процес формулисања стандарда контрадикције и њихову хијерархију. Циљ је постигнут интегрисањем преференција носиоца одлучивања.

Предложени приступ је илустрован студијом случаја једног система ветрогенератора. 